\title{
Synthesis and reactions of 3-aminotetrachloroquinazolin-2,4-dione
}

\author{
Mamdouh Adly Hassan, Ahmed Mohamed Mosalem Younes, \\ Mohamed Mobark Taha and Abou-Bakr Haredy Abdel-Monsef* \\ Chemistry Department, Faculty of Science, South Valley University, Qena-83523, Egypt \\ ${ }^{*}$ Corresponding author at: Chemistry Department, Faculty of Science, South Valley University, Qena-83523, Egypt. Tel.: +20.96 .5211281 ; fax: +20.96 .5211279$ \\ E-mail address: bakooos2004@yahoo.com (A.H. Abdel-Monsef).
}

\section{ARTICLE INFORMATION}

Received: 21 June 2011

Received in revised form: 31 July 2011

Accepted: 31 July 2011

Online: 31 December 2011

\section{KEYWORDS}

Quinazolinedione

Hydrazine hydrate

Anti-inflammatory

Tetrachloroquinazolindione

$\mathrm{N}$-Phenylsulphonyloxytetrachlorophthalimide

3-( $N$-acetylamino)tetrachloroquinazolindione

\section{Introduction}

Owing to the importance of tetrachlorophthalimides as good $\alpha$-glucosides inhibitors that decrease glucose level $[1,2]$ in blood and their use as potentially valuable for various diseases, we aimed in the present study to synthesize another class of new tetrachloroheterocyclic compounds such as tetrachloro quinazolindione derivatives. It has been recently shown that pyrimidines and quinazolindiones are important compounds posses pharmacological activity including use as anticonvulsant, electroshock, pentylenetetrazole induced seizures in mice [3], sedative, hypotensive [4], antinflammatory, antigonisys [5,6], vasodilator [7-9], contractile smooth muscles and posses inhibitory activity toward the calcium independent phosphordiesteras enzyme [10]. This encouraged us to synthesize quinazolinedione derivatives containing four chlorine atoms in benzene ring starting with tetrachlorophthalic anhydride which may possess greater certain pharmacological activities.

\section{Experimental}

\subsection{Instrumentation}

Melting points were uncorrected determined on an electric melting point apparatus (Kofler). The IR spectra (KBr) were recorded on a Shimadzu 408 spectrometer. The ${ }^{1} \mathrm{H}$ NMR spectra were recorded by $200 \mathrm{MHz}$ varian EM 390 spectrometer; chemical shifts are reported in ppm with TMS as an internal standard and are given in $\delta$ units. Electron impact mass spectra were obtained at $70 \mathrm{eV}$ using a GC-MS sp.1000 Shimadzu. Elemental analyses were carried out at Microanalysis Unit at Cairo University; purity of the compounds was detected by TLC.

\subsection{Synthesis}

\subsection{1. $N$-phenylsulphonyloxytetrachlorophthalimide (2)}

Benzenesulphonyl chloride was added dropwisely with stirring in ice bath to a solution of $N$-hydroxytetrachloro phthalimide $(6.3 \mathrm{~g}, 20 \mathrm{mmol})$ in pyridine $(15 \mathrm{~mL})$ [11]. The reaction mixture was vigorously stirred for $15 \mathrm{~min}$., the solid formed was acidified with cold dilute hydrochloric acid (1:1), and the solid formed was filtered off and dried. The target product was crystallized from petroleum ether (80-100) and benzene (3:1) to give $N$-phenylsulphonyloxytetrachlorophthalimide ( $3 \mathrm{~g}, 6.8 \mathrm{mmol}$ ) 2 in yield $35 \%$ as yellow crystals (Scheme 1). M.p.: $244{ }^{\circ} \mathrm{C}$. FT-IR $\left(\mathrm{KBr}, \mathrm{cm}^{-1}\right): 1808$ and 1750 (C=0), 1360 and 1180 ( $\left.\mathrm{SO}_{2}-\mathrm{O}-\right)$. ${ }^{1} \mathrm{H}$ NMR (300 MHz, DMSO-d6, ppm): 7.70- $8.11\left(\mathrm{~m}, 5 \mathrm{H}, \mathrm{Ph}-\mathrm{SO}_{2}\right)$. MS ( $\left.\mathrm{m} / \mathrm{z}, \%\right): 439(1.01 \%)$ correspond to the molecular formula $\left(\mathrm{C}_{14} \mathrm{H}_{5} \mathrm{Cl}_{4} \mathrm{NO}_{5} \mathrm{~S}\right)$ in addition to the characteristic peaks for compounds containing four chlorine atoms [13] at $(\mathrm{M}+2),(\mathrm{M}+4)$ and $(\mathrm{M}+6)$. Anal. calcd. for $\mathrm{C}_{14} \mathrm{H}_{5} \mathrm{Cl}_{4} \mathrm{NO}_{5} \mathrm{~S}$ : C, 38.12; H, 1.14; N, 3.18. Found: C, $38.31 ; \mathrm{H}, 1.16$; N, 3.18\%.

\subsubsection{3-aminotetrachloroquinazolin-2,4-dione (3)}

A mixture of $\mathrm{N}$-phenylsulphonyloxytetrachlorophthalimide, 2, (4.41 g, 10 mmole) and hydrazine hydrate in dry benzene (40 mL) using Dean \& starks' apparatus was refluxed for 2 hours [12]. After cooling; the solid formed was filtered off and crystallized from water to give 3-aminotetrachloroquinazolin2,4-dione (2.4 g, 7.6 mmole) 3 in yield $76 \%$ as white crystal (Scheme 2). M.p.: $274{ }^{\circ} \mathrm{C}$. FT-IR $\left(\mathrm{KBr}, \mathrm{cm}^{-1}\right): 3457(\mathrm{NH}), 3313$ and $3206\left(\mathrm{NH}_{2}\right), 1726$ and $1675(\mathrm{C}=0) .{ }^{1} \mathrm{H}$ NMR $(200 \mathrm{MHz}$, DMSO- $\left.d_{6}, \mathrm{ppm}\right): 5.62\left(\mathrm{~s}, 2 \mathrm{H}, \mathrm{NH}_{2}\right)$ and also showed the disappearance of NH signal in DMSO- $d_{6}$ while FT-IR spectrum revealed the presence of a band for $v \mathrm{NH}$ at $3457 \mathrm{~cm}^{-1}$. 


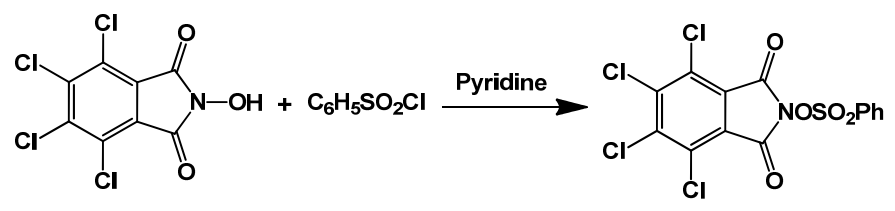

Scheme 1

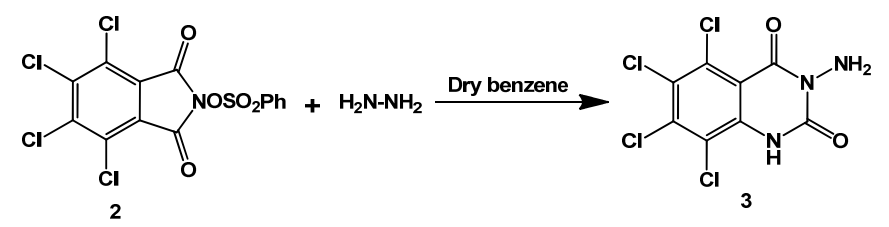

Scheme 2

Anal. calcd. for $\mathrm{C}_{8} \mathrm{H}_{3} \mathrm{Cl}_{4} \mathrm{~N}_{3} \mathrm{O}_{2}$ : C, 30.52; $\mathrm{H}, 0.96 ; \mathrm{N}, 13.34$. Found: C, 30.75; H, 0.97; N, $13.34 \%$.

\subsubsection{3-(N-acetylamino)tetrachloroquinazolin-2,4-dione (4)}

To a solution of 3-aminotetrachloroquinazolin-2,4-dione $\mathbf{3}$ $(0.315 \mathrm{~g}, 1 \mathrm{mmole})$ in dry pyridine $(10 \mathrm{~mL})$, acetylchloride (1 $\mathrm{mL})$ was added drop wisely at room temperature. The reaction mixture was stirred for 2 hours, and a cold diluted $\mathrm{HCl}$ (1:1) was added to the reaction mixture and the solid formed was filtered off and crystallized from benzene/ethanol to give 3-( $\mathrm{N}$-acetylamino)tetrachloroquinazolin-2,4-dione $(0.29 \mathrm{~g}, 0.81$ mmole) 4 in yield $81 \%$ as white crystal (Scheme 3). M.p.: 306 ${ }^{\circ} \mathrm{C}$. FT-IR $\left(\mathrm{KBr}, \mathrm{cm}^{-1}\right): 3200(\mathrm{NH}), 1780$ and $1750(\mathrm{C}=0)$ (imide carbonyl). ${ }^{1} \mathrm{H}$ NMR $\left(200 \mathrm{MHz}, \mathrm{DMSO}-d_{6}, \mathrm{ppm}\right): 1.93\left(\mathrm{~s}, 3 \mathrm{H}, \mathrm{CH}_{3}\right)$, $10.6(\mathrm{~S}, 1 \mathrm{H}, \mathrm{NH}), 11.4(\mathrm{~S}, 1 \mathrm{H}, \mathrm{NH})$. Anal. calcd. for $\mathrm{C}_{10} \mathrm{H}_{5} \mathrm{Cl}_{4} \mathrm{~N}_{3} \mathrm{O}_{3}$ : C, 33.65; H, 1.41; N, 11.77. Found: C, 33.86; H, 1.42; N, 11.98\%.

\subsubsection{3-(phenylsulphonylamino)tetrachloroquinazolin-2,4- dione (5)}

3-aminotetrachloroquinazolin-2,4-dione $\mathbf{3} \quad \begin{array}{lll}0.31 & \mathrm{~g}, & 1\end{array}$ mmole) in dry pyridine $(10 \mathrm{~mL})$ was cooled in ice bath; benzenesulphonyl chloride was added drop wisely. The reaction mixture with stirred at room temperature for 4 hours. A cold diluted $\mathrm{HCl}$ (1:1) was added to the reaction mixture and the solid formed was filtered off and crystallized from benzene/ethanol to give 3-(phenylsulphonylamino)tetrachloro quinazolin-2,4,dione $(0.27 \mathrm{~g}, 0.59$ mmole $) \mathbf{5}$ in yield $59 \%$ as yellow crystal (Scheme 3). M.p.: $300{ }^{\circ} \mathrm{C}$. FT-IR $\left(\mathrm{KBr}, \mathrm{cm}^{-1}\right): 3200$ $(\mathrm{NH}), 1810,1750(\mathrm{C}=0), 1360,1180\left(\mathrm{SO}_{2}\right) .{ }^{1} \mathrm{H}$ NMR $(200 \mathrm{MHz}$, DMSO- $\left.d_{6}\right)$ : 7.30-7.90 (m, 5H, Ar-H), $9.75(\mathrm{~s}, 1 \mathrm{H}, \mathrm{NH}), 11.40(\mathrm{~s}$, $1 \mathrm{H}, \mathrm{NH}$ ). Anal. Calcd. for $\mathrm{C}_{14} \mathrm{H}_{7} \mathrm{Cl}_{4} \mathrm{~N}_{3} \mathrm{O}_{4} \mathrm{~S}$. C, 36.95; H, 1.55; N, 9.23. Found: C, 37.23; H, 1.56; N, 9.34 \%.

\subsubsection{3-(2-thiophenecarbonylamino)tetrachloroquinazolin- 2,4-dione (6)}

A solution of 3-aminotetrachloroquinazolin-2,4-dione 3 $(0.31 \mathrm{~g}, 1 \mathrm{mmole})$ in dry pyridine $(10 \mathrm{~mL})$ was cooled in ice bath; 2-thiophenecarbonyl chloride was added drop wisely with stirring for 4 hours. A cold diluted $\mathrm{HCl}$ (1:1) was added to the reaction mixture and the solid formed was filtered off and crystallized from benzene/ethanol to give 3-(2-thiophenecarbonylamino)tetrachloroquinazolin-2,4-dione (0.28 g, 0.729 mmole) 6 in yield $67 \%$ as white crystal (Scheme 3). M.p.: 308 ${ }^{\circ} \mathrm{C}$. FT-IR (KBr, cm$\left.{ }^{-1}\right): 3200(\mathrm{NH}), 1740$ and $1680(\mathrm{C}=0) .{ }^{1} \mathrm{H}$ NMR (200 MHz, DMSO- $\left.d_{6}, \mathrm{ppm}\right):$ 7.26-7.28 (dd, $\left.1 \mathrm{H}, \mathrm{H}_{\mathrm{x}}\right), 7.96(\mathrm{dd}, 1 \mathrm{H}$, $\left.\mathrm{H}_{\mathrm{M}}\right), 7.98-8.02\left(\mathrm{dd}, 1 \mathrm{H}, \mathrm{H}_{\mathrm{A}}\right), 11.34(\mathrm{~s}, 1 \mathrm{H}, \mathrm{NH}), 11.55(\mathrm{~s}, 1 \mathrm{H}, \mathrm{NH})$.
MS (m/z, \%): $423(0.59 \%)\left(\mathrm{M}^{+}\right)$in addition to the characteristic peaks for compounds containing four chlorine atoms at $m / z=425(0.66 \%)(\mathrm{M}+2), 427(0.41 \%)(\mathrm{M}+4)$ and $429(0.08 \%)(\mathrm{M}+6)$. Anal. calcd. for $\mathrm{C}_{13} \mathrm{H}_{5} \mathrm{Cl}_{4} \mathrm{~N}_{3} \mathrm{O}_{3} \mathrm{~S}: \mathrm{C}, 36.74 ; \mathrm{H}$, 1.18; N, 9.88. Found: C, 36.98; H,1.19; N $10.05 \%$.

\subsubsection{3-(2-chloromethylcarbonylamino)tetrachloro quinazolin-2,4-dione (7)}

To a stirred solution of 3-aminotetrachloroquinazolin-2,4dione $3(0.31 \mathrm{~g}, 1 \mathrm{mmole})$ in DMF $(10 \mathrm{~mL})$, chloroacetylchloride (1 $\mathrm{mL})$ was added drop wisely at room temperature. The reaction mixture was stirred for 2 hours, and then dilute with cold water. The solid formed was filtered off and crystallized from benzene/ethanol to give 3-(2-chloromethylcarbonylamino)tetrachloroquinazolin-2,4-dione (0.35 g, 0.89 mmole) 7 in yield $89 \%$ as white crystal (Scheme 3). M.p.: $320{ }^{\circ}$ C. FT-IR ( $\mathrm{KBr}, \mathrm{cm}^{-1}$ ): $3211(\mathrm{NH}), 3021$ (CH Aliph.), 1741 and 1700 (C=0). ${ }^{1} \mathrm{H}$ NMR $\left(200 \mathrm{MHz}\right.$, DMSO- $\left.d_{6}, \mathrm{ppm}\right): 4.04\left(\mathrm{~s}, 2 \mathrm{H}, \mathrm{CH}_{2}\right), 11.2(\mathrm{~s}$, $1 \mathrm{H}, \mathrm{NH}), 11.58(\mathrm{~s}, 1 \mathrm{H}, \mathrm{NH})$. Anal. calcd. for $\mathrm{C}_{10} \mathrm{H}_{4} \mathrm{Cl}_{5} \mathrm{~N}_{3} \mathrm{O}_{3}$ : C, 30.69; H, 1.03; N, 10.73. Found: C, 30.81; H, 1.02; N 10.90\%.

\subsubsection{3-(N-benzamido)tetrachloroquinazolin-2,4-dione (8a)}

A solution of 3-aminotetrachloroquinazolin-2,4-dione 3 $(0.31 \mathrm{~g}, 1 \mathrm{mmole})$ in dry pyridine $(10 \mathrm{~mL})$ was cooled in ice bath; benzoylchloride was added drop wisely with stirring for 4 hours. A cold diluted $\mathrm{HCl}$ (1:1)was added to the reaction mixture and the solid formed was filtered off and crystallized from benzene/ethanol to give 3-( $N$-benzamido)tetrachloro quinazolin-2,4-dione ( $0.32 \mathrm{~g}, 0.76 \mathrm{mmole}$ ) $8 \mathrm{a}$ in yield $78 \%$ as white crystal (Scheme 3). M.p.: $310^{\circ} \mathrm{C}$. FT-IR $\left(\mathrm{KBr}, \mathrm{cm}^{-1}\right): 3200$ (NH), 3000 (CH arom.), 1740 and 1660 (C=0). ${ }^{1} \mathrm{H}$ NMR (200 MHz, DMSO- $\left.d_{6}, \mathrm{ppm}\right):$ 7.30-8.00 (m, $\left.5 \mathrm{H}, \mathrm{Ar}-\mathrm{H}\right), 11.30(\mathrm{~s}, 1 \mathrm{H}$, $\mathrm{NH}), 11.40$ (s, $1 \mathrm{H}, \mathrm{NH})$. Anal. calcd. for $\mathrm{C}_{15} \mathrm{H}_{7} \mathrm{Cl}_{4} \mathrm{~N}_{3} \mathrm{O}_{3}$. C, 42.99; $\mathrm{H}$, 1.68; N, 10.03. Found: C, 43.20; H, 1.66; N 10.07\%.

\subsubsection{3-[(N-(4-bromobenzamido)tetrachloroquinazolin-2,4- dione (8b)}

A mixture of 3-aminotetrachloroquinazolin-2,4-dione 3 (0.31 g, $1 \mathrm{mmole})$ and $p$-bromobenzoylchloride $(0.21 \mathrm{~g}, 1$ mmole) in dry pyridine $(10 \mathrm{~mL})$ was heated under reflux for $1 / 2$ hour. After cooling, the reaction mixture was poured into cold diluted HCl (1:1). The solid formed was filtered off and crystallized from benzene/ethanol to give 3-[( $N$ - (4-bromo benzamido)tetrachloroquinazolin-2,4-dione $(0.28 \mathrm{~g}, \quad 0.56$ mmole) 8b in yield $56 \%$ as white crystal (Scheme 3). M.p.: 314 ${ }^{\circ} \mathrm{C}$. 


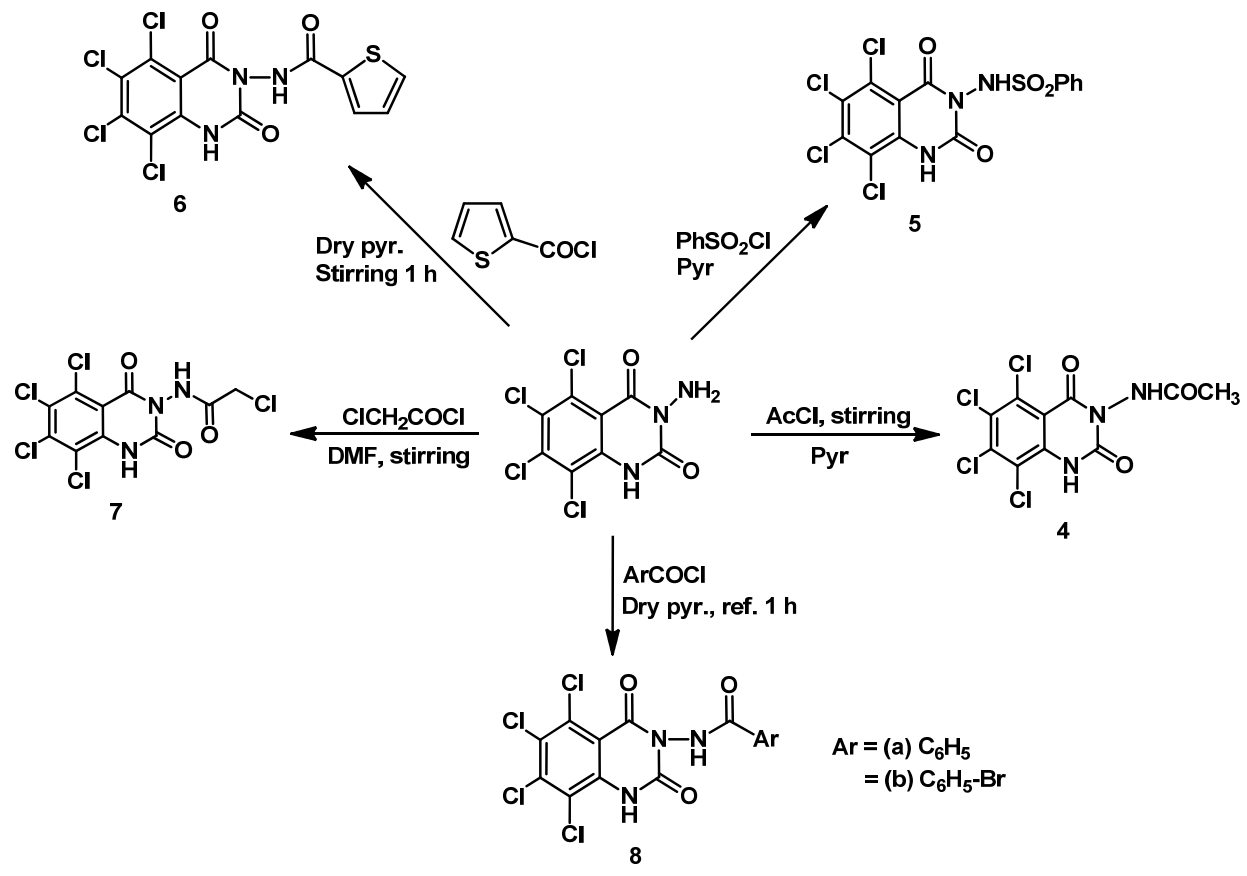

Scheme 3

FT-IR (KBr, cm-1): 3200 (NH), 3000 (CH Arom.), 1740 and 1660 $(\mathrm{C}=0) .{ }^{1} \mathrm{H}$ NMR $\left(200 \mathrm{MHz}, \mathrm{DMSO}-d_{6}, \mathrm{ppm}\right.$ ): 7.70-7.90 (two doublet $4 \mathrm{H}, \mathrm{A}_{2} \mathrm{~B}_{2}$ Arom.), 10.65 (s, 1H, NH), 11.47 (s, 1H, NH). Anal. calcd. for $\mathrm{C}_{15} \mathrm{H}_{6} \mathrm{BrCl}_{4} \mathrm{~N}_{3} \mathrm{O}_{3}$ : C, 36.18; $\mathrm{H}, 1.21 ; \mathrm{N}, 8.44$. Found: C, 36.28; H, 1.22; N 8.68\%.

\subsubsection{3-arylidineaminotetrachloroquinazolin-2,4-diones (9a-d)}

3-Aminotetrachloroquinazolin-2,4-dione 3 (0.31 g, 1 mmole) was heated under reflux for 10-12 hours with the appropriate aromatic aldehydes namely benzaldehyde, $p$-nitrobenzaldehyde, $\quad p$-chlorobenzaldehyde and thiophenecarbaldehyde ( 1 mmole) in absolute ethanol $(20 \mathrm{~mL})$ and in prescence of pipridine as a catalyst. After cooling; the reaction mixture was filtered off and crystallized from appropriate solvent to give the arylidine derivatives, 9a-d, respectively (Scheme 4).

3-(Benzylidene-amino)-5,6,7,8-tetrachloro-1H-quinazoline2,4-dione (9a): Yield: $77 \%$ as yellow crystal. M.p.: $360{ }^{\circ} \mathrm{C}$. FT-IR $\left(\mathrm{KBr}, \mathrm{cm}^{-1}\right): 3221(\mathrm{NH}), 1731,1685(\mathrm{C}=0) .{ }^{1} \mathrm{H}$ NMR $(200 \mathrm{MHz}$, DMSO- $\left.d_{6}, \mathrm{ppm}\right)$ : 7.54-7.95 (m, $5 \mathrm{H}$, arom. $\left.\mathrm{H}\right), 8.6(\mathrm{~s}, 1 \mathrm{H}, \mathrm{CH}=\mathrm{N})$, $11.45(\mathrm{~s}, 1 \mathrm{H}, \mathrm{NH})$. Anal. calcd. for $\mathrm{C}_{15} \mathrm{H}_{7} \mathrm{Cl}_{4} \mathrm{~N}_{3} \mathrm{O}_{2}$ : C, 44.71; $\mathrm{H}$, $1.75 ; \mathrm{N}, 10.42$. Found: C, 44.94; H, 1.76; N $10.59 \%$.

3-(Nitrobenzylidene-amino)-5,6,7,8-tetrachloro- $1 \mathrm{H}$ quinazoline-2,4-dione (9b): Yield: $64 \%$ as brown silky. M.p.: $360{ }^{\circ} \mathrm{C}$. FT-IR (KBr, cm${ }^{-1}$ ): 3389 (NH), 1726, 1623 (C=0). ${ }^{1} \mathrm{H}$ NMR (200 MHz, DMSO- $d_{6}$, ppm): 8.24-8.42 (two d, $4 \mathrm{H}, \mathrm{A}_{2} \mathrm{~B}_{2}$ arom.), $8.93(\mathrm{~s}, 1 \mathrm{H}, \mathrm{CH}=\mathrm{N}), 11.20(\mathrm{~s}, 1 \mathrm{H}, \mathrm{NH})$. Anal. calcd. for $\mathrm{C}_{15} \mathrm{H}_{7} \mathrm{Cl}_{4} \mathrm{~N}_{3} \mathrm{O}_{2}: \mathrm{C}, 40.22 ; \mathrm{H}, 1.35 ; \mathrm{N}, 12.51$. Found: $\mathrm{C}, 40.51 ; \mathrm{H}$, 1.36; N $12.65 \%$.

3-(Chlorobenzylidene-amino)-5,6,7,8-tetrachloro-1Hquinazoline-2,4-dione (9c): Yield: $60 \%$ as yellow crystal. M.p.: $272{ }^{\circ} \mathrm{C} .{ }^{1} \mathrm{H}$ NMR $\left(200 \mathrm{MHz}\right.$, DMSO- $d_{6}, \mathrm{ppm}$ ): 7.63-7.90 (two d, $4 \mathrm{H}, \mathrm{A}_{2} \mathrm{~B}_{2}$ arom.), $8.79(\mathrm{~s}, 1 \mathrm{H}, \mathrm{CH}=\mathrm{N}), 11.4(\mathrm{~s}, 1 \mathrm{H}, \mathrm{NH})$. Anal. calcd. for $\mathrm{C}_{15} \mathrm{H}_{6} \mathrm{Cl}_{5} \mathrm{~N}_{3} \mathrm{O}_{2}$ : C, 41.19; $\mathrm{H}, 1.38 ; \mathrm{N}, 9.60$. Found: C, 41.29; $\mathrm{H}, 1.39$; $\mathrm{N} 9.89 \%$.

5,6,7,8-Tetrachloro-3-[(thiophen-2-ylmethylene)-amino]-1Hquinazoline-2,4-dione (9d): Yield: $74 \%$ as yellow crystal. M.p.:
$320{ }^{\circ} \mathrm{C}$. FT-IR (KBr, cm-1): 3493 (NH), 3108-3032 (CH aliph), 1751, $1695(\mathrm{C}=0) .{ }^{1} \mathrm{H}$ NMR $\left(200 \mathrm{MHz}, \mathrm{DMSO}-\mathrm{d}_{6}\right)$ : $7.30(\mathrm{dd}, 1 \mathrm{H}$, $\left.\mathrm{H}_{\mathrm{x}}\right), 7.78\left(\mathrm{dd}, 1 \mathrm{H}, \mathrm{H}_{\mathrm{M}}\right), 7.96\left(\mathrm{dd}, 1 \mathrm{H}, \mathrm{H}_{\mathrm{A}}\right), 8.8(\mathrm{~s}, 1 \mathrm{H}, \mathrm{CH}=\mathrm{N})$, 11.22 (s, $1 \mathrm{H}, \mathrm{NH}$ ). Anal. calcd. for $\mathrm{C}_{13} \mathrm{H}_{5} \mathrm{Cl}_{4} \mathrm{~N}_{3} \mathrm{O}_{2} \mathrm{~S}: \mathrm{C}, 38.17 ; \mathrm{H}$, 1.23; N, 10.27. Found: C, 38.38; H, 1.24; N 10.51\%.

\subsubsection{0. $\mathrm{N}$-(5,6,-7,8-tetrachloro-2,4-dioxo-1,4-dihydro-2H- quinazolin-3-yl)-malonamic acid ethyl ester (10)}

A mixture of 3-aminotetrachloroquinazolin-2,4-dione 3 (0.31 g, $1 \mathrm{mmole})$ and diethylmalonate was refluxed for 6 hours. After cooling; the reaction mixture was filtered off and crystallized from benzene/ethanol to give $N-(5,6,7,8-$ tetrachloro-2,4-dioxo-1,4-di-hydro-2H-quinazolin-3-yl)malonamic acid ethyl ester (0.34 g, 0.75 mmole) 10 in yield $78 \%$ as white crystal (Scheme 4). M.p.: $310{ }^{\circ} \mathrm{C}$. FT-IR $\left(\mathrm{KBr}, \mathrm{cm}^{-1}\right): 3200$ $(\mathrm{NH}), 1740$ and $1660(\mathrm{C}=0)$. ${ }^{1} \mathrm{H}$ NMR $\left(200 \mathrm{MHz}, \mathrm{DMSO}-d_{6}\right.$, ppm): 1.18 (t, 3H, $\left.\mathrm{CH}_{3}\right), 3.50$ (s, 2H, $\left.\mathrm{CH}_{2}-\mathrm{CO}\right), 4.13$ (q, 2H, $\mathrm{CH}_{2}$ $0), 10.90(\mathrm{~s}, 1 \mathrm{H}, \mathrm{NH}), 11.44(\mathrm{~s}, 1 \mathrm{H}, \mathrm{NH})$. Anal. calcd. for $\mathrm{C}_{13} \mathrm{H}_{9} \mathrm{Cl}_{4} \mathrm{~N}_{3} \mathrm{O}_{5}$ : C, 36.39; H, 2.11; N, 9.79. Found: C, 36.69; H, 2.12; $\mathrm{N}$ 9.98\%.

\subsubsection{3-(ethoxymethylidineamino)tetrachloroquinazolin- 2,4-dione (11)}

Triethylorthoformate is added to 3-aminotetrachloro quinazolin-2,4-dione 3 (0.31 g, $1 \mathrm{mmole})$. The mixture was refluxed for 6 hours, and then allowed to stand overnight. The precipitated product was collected and crystallized from benzene to give 3-(ethoxymethylidineamino)tetrachloro quinazolin-2,4-dione ( $0.27 \mathrm{~g}, 0.72 \mathrm{mmole}) \mathbf{1 1}$ in yield $72 \%$ as yellow crystal (Scheme 4). M.p.: $182{ }^{\circ} \mathrm{C}$. FT-IR $\left(\mathrm{KBr}, \mathrm{cm}^{-1}\right)$ : 3293 $(\mathrm{NH}), 1741$ and $1660(\mathrm{C}=0) .{ }^{1} \mathrm{H}$ NMR $\left(200 \mathrm{MHz}, \mathrm{DMSO}-d_{6}\right.$, ppm): 1.37 (two interfered triplets for the two isomeric $\mathrm{CH}_{3}$ protons), 4.39 two quartets for $\mathrm{CH}_{2}(\mathrm{Z}), 4.55$ for $\mathrm{CH}_{2}$ (E) in integration ratio (2:3), respectively, $7.98(\mathrm{~s}, 1 \mathrm{H}, \mathrm{CH}(Z)), 8.20(\mathrm{~s}$, $1 \mathrm{H}, \mathrm{CH}(E)), 11.22(\mathrm{~s}, 1 \mathrm{H}, \mathrm{NH})$. Anal. calcd. for $\mathrm{C}_{11} \mathrm{H}_{7} \mathrm{Cl}_{4} \mathrm{~N}_{3} \mathrm{O}_{3}: \mathrm{C}$, 35.61; H, 1.90; N, 11.33. Found: C, 35.85; H, 1.91; N 11.52\%. 


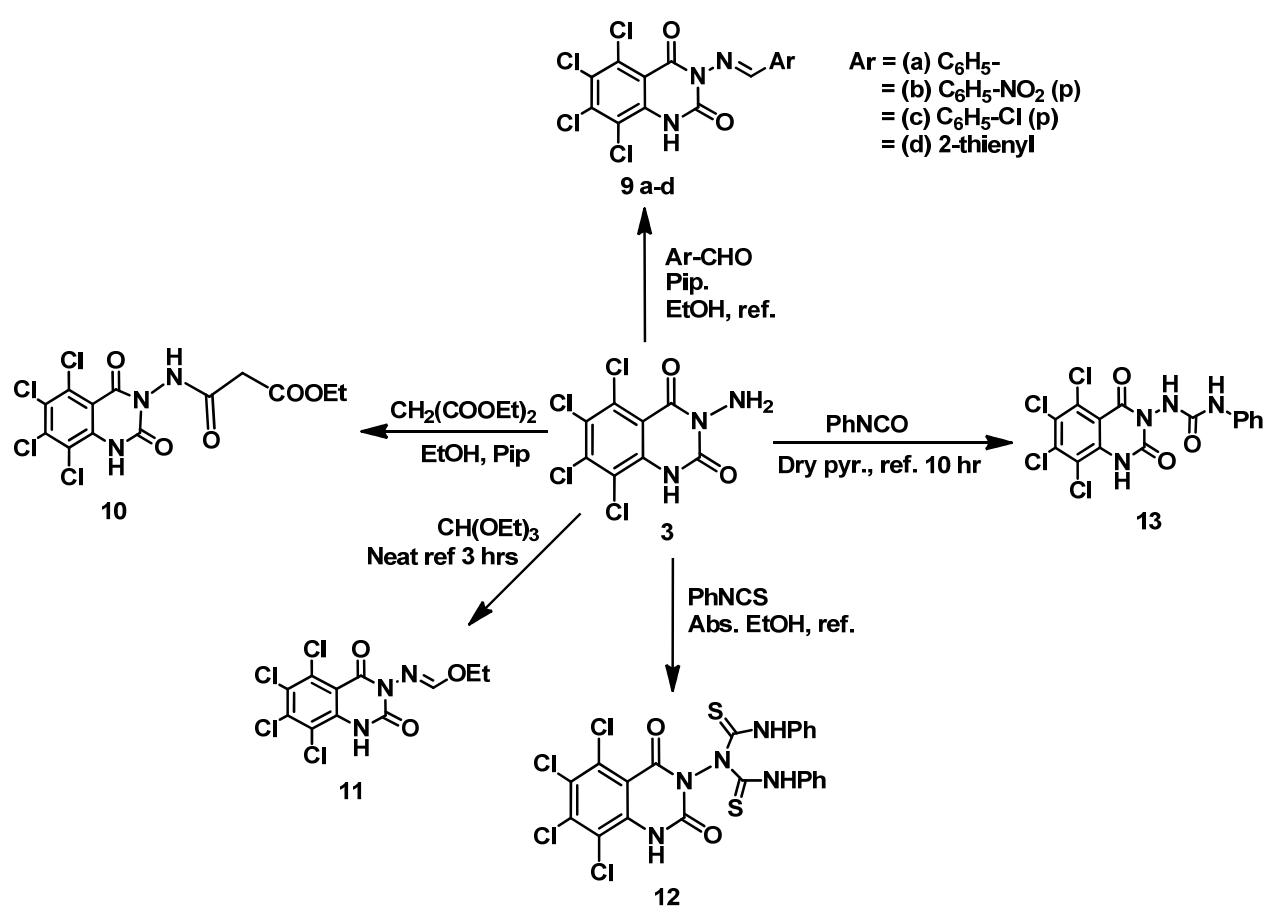

Scheme 4

\subsubsection{2. $N$-phenylthiocarbamoyl-N-tetrachloroquinazolin-2,4- dione- $N$ '-pheny-Ithiourea (12)}

Heating of 3-aminotetrachloroquinazolin-2,4-dione 3 (0.31 $\mathrm{g}, 1 \mathrm{mmole})$ with phenylisothiocyanate in absolute ethanol (20 $\mathrm{mL}$ ) under reflux for 6 hours gave after cooling a solid product which was filtered off and crystallized from benzene to give $N$ phenylthiocarbamoyl- $N$-tetrachloroquinazolin-2,4-dione- $N$ 'phenylthiourea ( $0.37 \mathrm{~g}, 0.62 \mathrm{mmole}) \mathbf{1 2}$ in yield $63 \%$ as white crystal (Scheme 4). M.p.: $210{ }^{\circ} \mathrm{C}$. FT-IR $\left(\mathrm{KBr}, \mathrm{cm}^{-1}\right)$ : 3231, 3185, $3129(\mathrm{NH}), 1731$ and $1695(\mathrm{C}=0) .{ }^{1} \mathrm{H}$ NMR $\left(200 \mathrm{MHz}\right.$, DMSO- $d_{6}$, ppm): 6.90-7.57 (m, $10 \mathrm{H}$, aromatic), 9.80 (s, 1H, HN-CS), 11.20 (s, $1 \mathrm{H}$, quinazoline $\mathrm{NH}$ ). Anal. calcd. for $\mathrm{C}_{22} \mathrm{H}_{13} \mathrm{Cl}_{4} \mathrm{~N}_{5} \mathrm{O}_{2} \mathrm{~S}_{2}$ : C, 45.15; H, 2.24; N, 11.96. Found: C, 45.41; H, 2.25; N 12.15\%.

\subsubsection{3. $N$-phenyl- $N$ '-[(1H,3H)-5,6,7,8-tetrachloroquinazolin- 2,4-dion-3-yl]urea (13)}

When a mixture of 3-aminotetrachloroquinazolin-2,4-dione $3(0.31 \mathrm{~g}, 1 \mathrm{mmole})$ and phenyl thiocyanate in dry pyridine $(10$ $\mathrm{mL}$ ) was refluxed for 10 hours. After cooling; the reaction mixture was poured into ice-water and the solid formed was filtered off and crystallized from benzene to give $N$-phenyl- $N$ '[(1H,3H)-5,6,7,8-tetrachloro-quinazolin-2,4-dion-3-yl]urea (0.25 g, 0.57 mmole) 13 in yield $57 \%$ (Scheme 4). M.p.: 194 oC. FT-IR (KBr, cm$\left.{ }^{-1}\right): 3200(\mathrm{NH}), 1740$ and $1660(\mathrm{C}=0) .{ }^{1} \mathrm{H}$ NMR (200 MHz, DMSO- $\left.d_{6}, \mathrm{ppm}\right): 6.98-7.50(\mathrm{~m}, 5 \mathrm{H}$, aromatic), 8.70 (s, 1H, NH), $10.90(\mathrm{~s}, 1 \mathrm{H}, \mathrm{NH}), 11.80(\mathrm{~s}, 1 \mathrm{H}, \mathrm{NH})$. Anal. calcd. for $\mathrm{C}_{15} \mathrm{H}_{8} \mathrm{Cl}_{4} \mathrm{~N}_{4} \mathrm{O}_{3}$ : C, 41.51; $\mathrm{H}, 1.85 ; \mathrm{N}, 12.91$. Found: $\mathrm{C}, 41.78 ; \mathrm{H}$, 1.86; N $13.18 \%$.

\subsubsection{Antibacterial studies}

Sallmonela typhi, staphylococcus aureus, bacillus cereus and bacillus subtilis were obtained from the Faculty of Veterinary Medicine, Pathology Department, Qena, Egypt. All the bacteria were grown on the desired media until the desired growth was obtained.
Disc diffusion test [14]: Whatman paper No. 1 filter paper was used to make sterile disc in order to screen for the antibacterial activity of Sallmonela typhi, Staphylococcus aureus, Bacillus cereus and Bacillus subtilis. This filter paper was punctured to the shape of commercial antibiotic disc and discs were autoclaved at $121{ }^{\circ} \mathrm{C}$ for $15 \mathrm{~min}$. The suspension of bacteria culture was prepared according to the MacFarland standard 0.5 and was lawned onto the Mueiller Hinton agar plates to produce the bacteria field. A sterile of punctured filter papers was placed on the bacteria field by sterile forceps and the solubilized extract then was pipetted out onto the surface of filter paper on the bacteria field. Tetracycline and DMF was used as a positive and negative control. The concentration of the compounds tested was $50 \mathrm{mg} / \mathrm{mL}$. Finally, the plate was incubated at $37^{\circ} \mathrm{C}$ and the zone inhibition is observed after 24 $48 \mathrm{~h}$ and measured as $\mathrm{mm}$.

\section{Results and discussion}

\subsection{Synthesis}

As a part of our program aimed to synthesize new pyrimidine derivatives as potential pharmaceuticals and/or agrochemicals, we report here the synthesis of new tetrachloroheterocyclic compounds such as tetrachloro quinazolindione derivatives. Treatment of $\mathrm{N}$-hydroxytetra chlorophthalimide with benzenesulphonyl chloride gave compound 2, which identified as $\mathrm{N}$-phenylsulphonyloxytetrachlorophthalimide (Scheme 1). The main fragmentation routes for compound 2 are shown in Scheme 5.

Treatment of $\mathrm{N}$-phenylsulphonyloxytetrachlorophthalimide 2 with excess hydrazine hydrate in dry benzene afforded 3aminotetrachloroquinazolin-2,4-dione, 3 (Scheme 3). The reaction of $\mathrm{N}$-phenylsulphonyloxytetrachlorophthalimide, 2, with hydrazine may proceed according to the following mechanism (Scheme 6).

The reaction of compound $\mathbf{3}$ with different acid chlorides was intensively investigated. Several 3-substituted 
tetrachloroquinazolin-2,4-diones, $\mathbf{4}, \mathbf{5}, \mathbf{6}, \mathbf{7}, \mathbf{8 a}$ and $\mathbf{8 b}$ were prepared via treatment of 3-aminotetrachloroquinazolin-2,4dione 3 with acid chlorides namely acetylchloride, benzene sulphonylchloride, 2-thiophenecarbonyl-chloride, chloroacetyl chloride, benzoylchloride and $p$-bromobenzoylchloride (Scheme 3).

The reactions of compound $\mathbf{3}$ with different aldehydes, diethylmalonate, triethylorthoformate, phenyl isothiocyanate and phenyl thiocyanate were intensively investigated. Several 3-arylidineaminotetrachloroquinazolin-2,4-diones 9a-d have been prepared via treatment of 3-aminotetrachloroquinazolin2,4-dione, 3, with different aldehydes, namely benzaldehyde, $p$-nitrobenzaldehyde, $p$-chlorobenzaldehyde and thiophene carbaldehyde (Scheme 4). Also, 3-aminotetrachloroquinazolin2,4-dione, 3, reacted with diethylmalonate, triethylorthoformate, phenyl isothiocyanate and phenyl thiocyanate to give $N$-(5,6,-7,8-tetrachloro-2,4-dioxo-1,4-dihydro-2H-quinazolin-3yl)-malonamic acid ethyl ester, 10, 3-(ethoxymethylidineamino)tetrachloroquinazolin-2,4-dione, 11, $N$-phenylthio carbamoyl- $N$-tetrachloroquinazolin-2,4-dione- $N N^{\prime}$-phenylthiourea, 12, and $N$-phenyl- $N^{\prime}-[(1 \mathrm{H}, 3 \mathrm{H})-5,6,7,8$-tetrachloro quinazolin-2,4-dion-3-yl]urea, 13, respectively (Scheme 4).

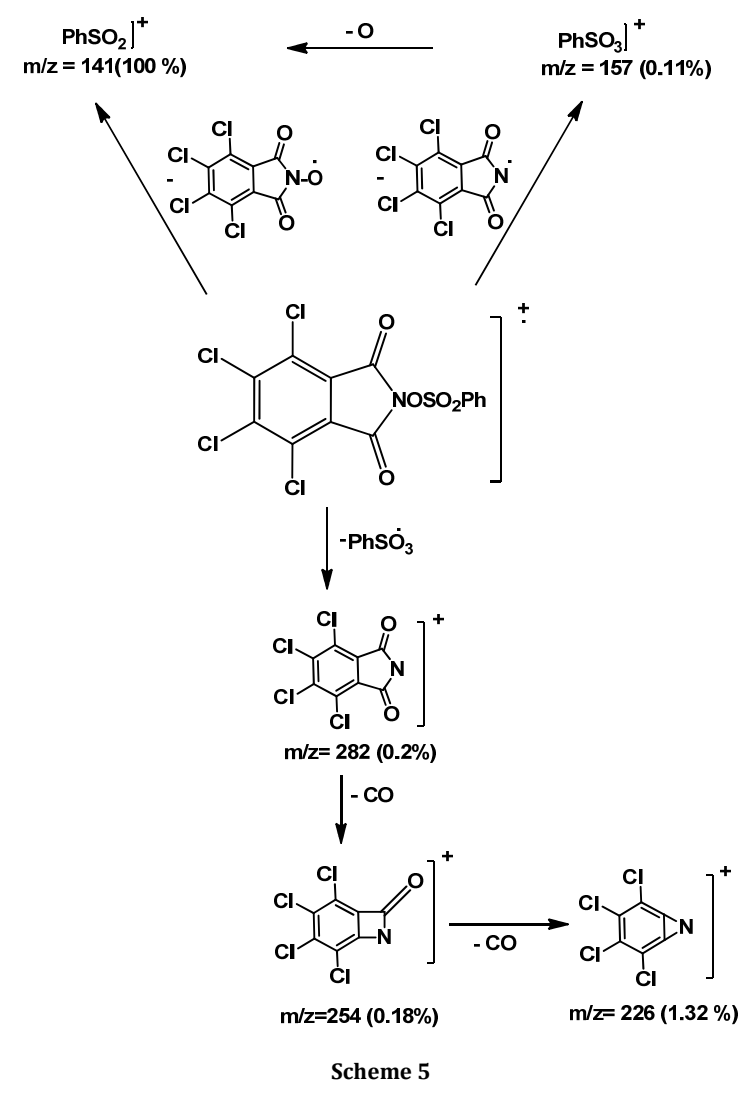

\subsection{Antibacterial Assays}

The compound $\mathbf{3}$ exhibited anti-bacterialactivity against Staph. areus $(8 \mathrm{~mm})$, Bacillus cereus $(15 \mathrm{~mm})$ and Bacillus subtilis $(9 \mathrm{~mm})$. On the other hand this compound didn't show any inhibition activity against Salmonella typhi. This may be due to four chlorine [15] atoms and pyrimidine ring [16-18]. The activity of compound $\mathbf{7}$ against all microorganisms tested showed positive reactions as indicated by zone of inhibition $\mathbf{7}$, $\mathbf{9}, \mathbf{1 8}, 10 \mathrm{~mm}$, respectively, this may be due to and five chlorine atoms, respectively. The compound $\mathbf{8 a}$ showed the most activity against bacteria such as Bacillus Subtilis $(29 \mathrm{~mm})$ which is $2 \mathrm{~mm}$ more than the zone around tetracycline disc $(27 \mathrm{~mm})$; this may be due to presence of (HN-CO-Ph). The Compound $\mathbf{8 b}$ has antimicrobial effect due to presence of bromine atom [19]. The Compound $\mathbf{9 b}$ has antimicrobial effect due to presence of $\left(\mathrm{NO}_{2}\right)$ group. The compounds $\mathbf{9 d}$ and $\mathbf{1 0}$ showed most activity against Bacillus Subtilis (18 $\mathrm{mm}$ and $19 \mathrm{~mm}$, respectively). This may be due presence of (HN-CO) group in two compounds.
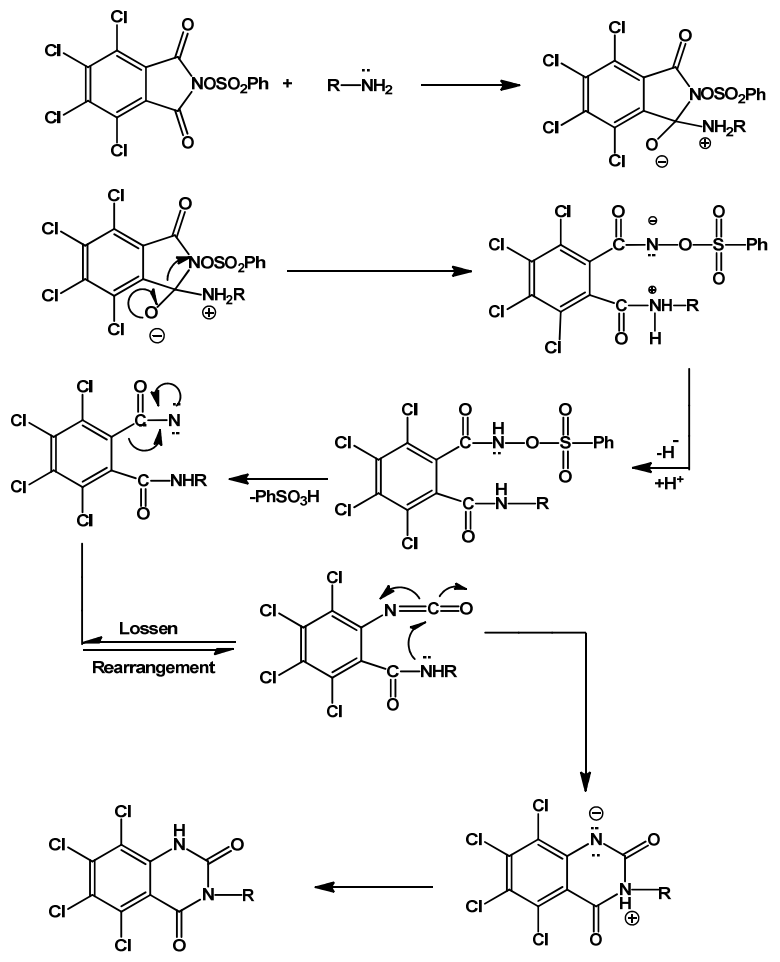

Scheme 6

\section{Acknowledgements} help.

The authors are grateful to Dr. Yousif Hassn Ebied for his

\section{References}

[1]. Agrawal, J. P.; Chouk M. P. Res. Ind. J. 1982, 27, 19-21.

[2]. Sou, S.; Mayumi, S.; Takahashi, H.; Yamasaki, R.; Kadoya, S.; Sodeoka, M.; Hashimoto, Y. Bioorg. Med. Chem. Lett. 2000, 10, 1081-1086.

[3]. Valencia, R.; Mason M. J.; Woodruff C. R.; Zimmering, S. Environ Mutagen. 1985, 7, 325-348.

[4]. Wenzel, D. G. J. Am. Pharm. Assoc. 1995, 44, 550-553.

[5]. Hansen, P.; Pederesen, E. B. Acta Chem. Scand. 1990, 44, 522-523.

[6]. Maillard, J.; Vincent M.; Benard, M. Chem. Ther. 1968, 3, 100-106.

[7]. Hong, E. U. S. Patent 3726979. Chem. Abstract. 1973, 79, 27560a.

[8]. Akgun, H.; Hollstein, U.; Hrwitz L. J. Pharm. Sci. 1988, 77, 735-739.

[9]. Havera, H. J.; Vidiro H. J. Med. Chem. 1979, 22, 1548-1550.

[10]. Havera H. J. Ger. Patent 242858, (1979). Chem. Abstract 1975, 82, $171029 p$.

[11]. Fahmy, A. F. M.; Youssef, M. S. K.; Abdel Halim, M. S.; Hassan M. A.; Saur, J. Heterocycles 1986, 24, 2201-2213.

[12]. Fahmy, A. F. M.; Aly, N. F.; Nada A.; Aly N. Y. Bull. Chem. Soc. Jpn. 1977, 50, 2678-2681.

[13]. Silverstein, R. M.; Bassler, G. C.; Morrill, T. C. Spectrometric Identification of Organic Compounds, John Wiley, 1916, 35.

[14]. Seeley, H. W.; VanDemank, P. J. Selected Exercises from Microbes in Action A laboratory Manual of Microbiology, $3^{\text {rd }}$ Ed., W.H. Freeman \& Co Ltd., 1981.

[15]. Ryan, K. J; Ray, C. G. Sherris Medical Microbiology (4th edn), McGraw Hill. ISBN 0-8385-8529-9, 2004.

[16]. Selassie, C. D.; Li, R.; Poe, M.; Hansch, C. J. Med. Chem. 1991, 34, 46-54.

[17]. Cheng, C. C. Prog. Med. Chem. 1969, 6, 67-134.

[18]. Nair-Scott, D. B. M.; Ulbrich, T. L. V.; Rogers, M. L.; Chu, E.; Rose, C. Cancer Res. 1959, 19, 15-19.

[19]. Narla, R. K.; Myres, D. E. Clin. Cancer Res. 1998, 4, 1405-1414. 